\title{
Pharmacokinetics of a New Fentanyl Tape with a Novel Delivery System of Transdermal Matrix Patches in Patients with Cancer Pain
}

\author{
Takefumi Saito $^{a}$ Masato Fujii ${ }^{b}$ Shiro Saito ${ }^{c}$ Ken Shimada $^{d}$ Keiichi Fujiwara $^{e}$ \\ Kunihiko Kobayashi ${ }^{f}$ \\ a Department of Respiratory Medicine, National Hospital Organization, Ibaraki Higashi National Hospital, Ibaraki, \\ Departments of ${ }^{b}$ Otolaryngology and ${ }^{C}$ Urology, National Hospital Organization, Tokyo Medical Center, Tokyo,

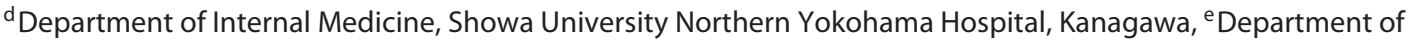 \\ Respiratory Medicine, National Hospital Organization, Okayama Medical Center, Okayama, and f Department of \\ Respiratory Medicine, Saitama Medical University, International Medical Center, Hidaka, Japan
}

\section{Key Words \\ Cancer · Fentanyl · Pain · Patch $\cdot$ Pharmacokinetics}

\begin{abstract}
Objectives: A novel delivery system for transdermal matrix patches of fentanyl has been developed. The new fentanyl tape consists of a backing layer, a drug-containing layer and a release liner that is originally made of rubber adhesive. This open-label prospective study investigated the pharmacokinetics and safety of the fentanyl tape in patients with cancer pain. Methods: The tape was applied to the patient's chest for $72 \mathrm{~h}$, and serum samples were collected from 0 to $72 \mathrm{~h}$. Fentanyl concentrations were determined using liquid chromatography with mass spectrometry. Pharmacokinetic parameters were calculated, and adverse events were evaluated according to the Common Terminology Criteria for Adverse Events (version 3.0). Results: Since 1 patient treated with $2.1 \mathrm{mg}$ fentanyl was found to represent unique pharmacokinetic parameters by Shapiro-Wilk test, only 15 of the 16 study patients were investigated. Maximum serum concentrations $\left(C_{\max }\right)$ and area under the curve $(A \cup C)_{0-72}$ at 2.1 and $4.2 \mathrm{mg}$ were 0.26 and $0.35 \mathrm{ng} / \mathrm{ml}$, and 11.58 and $15.95 \mathrm{ng} \cdot \mathrm{h} /$ $\mathrm{ml}$, respectively. The $C_{\max }$ and $A \cup C_{0-72}$ tended to increase
\end{abstract}

\begin{tabular}{ll}
\hline KARGER & $\begin{array}{l}\text { ( } 2013 \text { S. Karger AG, Basel } \\
0030-2414 / 13 / 0861-0010 \$ 38.00 / 0\end{array}$ \\
$\begin{array}{l}\text { E-Mail karger@karger.com } \\
\text { www.karger.com/ocl }\end{array}$ & $\begin{array}{l}\text { This is an Open Access article licensed under the terms of the } \\
\text { Creative Commons Attribution-NonCommercial 3.0 Un- } \\
\text { ported license (CC BY-NC) (www.karger.com/OA-license), } \\
\text { applicable to the online version of the article only. Distribu- } \\
\text { tion permitted for non-commercial purposes only. }\end{array}$
\end{tabular}

with dosage from 2.1 to $4.2 \mathrm{mg}$. There were no grade 3 toxicities, and only grade 1 ALT and AST elevations were observed. Conclusion: The novel delivery system of fentanyl may be a very promising approach to manage cancer pain clinically.

(c) 2013 S. Karger AG, Basel

\section{Introduction}

Potent opioids such as morphine, hydromorphone, oxycodone, piritramide, pethidine or the members of the fentanyl group are the basis for step 3 of the WHO ladder in cancer pain treatment. The $\mu$-receptor agonist, fentan$\mathrm{yl}$, possessing 100 times the potency of morphine $[1,2]$, is the most potent opioid routinely administered during cancer pain therapy, and fentanyl has been increasingly used since the early 1990s for treatment of cancer pain.

Due to its low molecular weight and high lipid solubility, fentanyl is suitable for transdermal delivery. Fentanyl is absorbed from the skin at a certain rate, and its serum concentrations are maintained in a steady state. Particularly in the outpatient setting, the development of a therapeutic system which is noninvasive and long lasting 
(usually 3 days) is highly appreciated. Fentanyl tapes are indicated in patients with moderate-to-severe, persistent cancer pain in need of opioid administration. There is a minimum effective concentration of fentanyl to be used in pain-controlling analgesia. However, adverse effects limit the usage of opioids [3].

In order to use fentanyl safely, adequately and without adverse events, it is important to investigate its pharmacokinetics. However, in Japanese cancer patients, there is no pharmacokinetic evidence for a detailed serum concentration profile of the fentanyl tape (transdermal matrix patches). In this open-label prospective study, we therefore investigated the pharmacokinetics and safety of the new fentanyl tape with a novel delivery system of transdermal matrix patches at dosages of 2.1 and $4.2 \mathrm{mg}$ in patients with cancer pain.

\section{Patients and Methods}

\section{Drugs}

We developed a novel delivery system of fentanyl tapes given as transdermal matrix patches (patented). The new fentanyl tape consists of a backing layer, a drug-containing layer and a release liner, which is originally made of rubber adhesive. A novel delivery system of fentanyl using a rubber adhesive in a release liner was developed, and the rubber adhesive results in little irritability and good adhesion to the skin.

\section{Study Protocol}

This open-label, prospective study investigated the pharmacokinetics and safety of the fentanyl tape at dosages of 2.1 and $4.2 \mathrm{mg}$ in patients with cancer pain. This study was performed in accordance with the Declaration of Helsinki (1964, amended in 2008) of the World Medical Association, and the study protocol was approved by the institutional review board of each participating institution. The main eligibility criteria included inpatients with cancer pain who were treated with opioids at a dosage of morphine equivalent to $10-134 \mathrm{mg} /$ day. Inclusion criteria were age $\geq 20$ years and ALT $<100 \mathrm{IU} / \mathrm{l}, \mathrm{AST}<100 \mathrm{IU} / \mathrm{l}$, serum creatinine $<2.0 \mathrm{mg} / \mathrm{dl}$ and body temperature $<38.4^{\circ} \mathrm{C}$.

After informed consent was obtained, oxycodone and morphine were switched to the fentanyl tape at doses of 2.1 or $4.2 \mathrm{mg}$, respectively, which was considered to be equivalent in efficacy. Oxycodone $<30 \mathrm{mg}$ or morphine $<45 \mathrm{mg}$ was switched to the 2.1$\mathrm{mg}$ fentanyl tape, and oxycodone from 30 to $89 \mathrm{mg}$ or morphine from 46 to $134 \mathrm{mg}$ were switched to the $4.2-\mathrm{mg}$ fentanyl tape. The tape was applied on the patient's chest for $72 \mathrm{~h}$, and serum samples ( $2 \mathrm{ml}$ each) were collected before dosing (0) and 8, 24, 32, 48, 56 and $72 \mathrm{~h}$ after application. In 3 patients treated with $2.1 \mathrm{mg}$, serum samples were also collected 80 and $96 \mathrm{~h}$ after application. Serum was separated by centrifugation and stored at $-20^{\circ} \mathrm{C}$ until analysis.

Adverse events, including skin toxicity, occurring during the $96 \mathrm{~h}$ after application were assessed using the Common Terminology Criteria for Adverse Events (version 3.0).

Pharmacokinetics of a New Fentanyl Tape
Analytical Methods

Pharmacokinetics

Fentanyl concentrations were determined using liquid chromatography with mass spectrometry. For serum fentanyl density measurements, bupivacaine was added as an internal standard to human serum, and serum samples were applied to solidphase extraction cartridge [OASIS MCX $\left.1 \mathrm{~cm}^{3}(30 \mathrm{mg})\right]$. Then, samples were eluted, followed by washing and desiccation. Finally, they were analyzed with liquid chromatography tandemmass spectrometry detection. Inter- and intra-assay coefficients of variation were satisfactory (precision $<15 \%$ and accuracy $<15 \%)$.

Maximum peak concentrations $\left(\mathrm{C}_{\max }\right)$ and time to $\mathrm{C}_{\max }\left(\mathrm{t}_{\max }\right)$ of fentanyl were obtained directly from the serum concentrationtime data. The area under the serum concentration-time curve from 0 to the last measurable sampling point $\left(\mathrm{AUC}_{0-72}\right)$ was calculated by the trapezoidal rule. The elimination rate constant $(\mathrm{k})$ value was estimated by log-linear regression of the terminal serum concentration-time data. The elimination half-life $\left(t_{1 / 2}\right)$ was calculated from 72 to $96 \mathrm{~h}$ as follows: $\mathrm{t}_{1 / 2}=0.693 / \mathrm{k}$. All pharmacokinetic parameters are given as means and SD.

Relationships between Clinical Parameters and $\mathrm{C}_{\max }$ or AUC $_{0-72}$

Linear regression and correlation (Pearson's correlation) were analyzed between clinical parameters [age, body mass index (BMI), ALT, AST or serum creatinine] and $\mathrm{C}_{\max }$ or $\mathrm{AUC}_{0-72} \cdot \mathrm{C}_{\max }$, $\mathrm{AUC}_{0-72}$ and $\mathrm{t}_{1 / 2}$ were compared between doses by $\mathrm{t}$ test.

\section{Results}

\section{Patient Characteristics}

Sixteen patients with cancer pain were enrolled in this study, and the demographic features of these patients are summarized in table 1 . All the patients were males, and ranged in age from 56 to 81 years. Their heights and body weights were from 157.7 to $174.0 \mathrm{~cm}$ and from 46.7 to $72.0 \mathrm{~kg}$, respectively, resulting in a mean BMI of 21.7 (range: 17.8-27.5) for the patients applied the 2.1-mg fentanyl tape and a mean BMI of 20.4 (range: 18.4-22.3) for those applied the 4.2-mg tape. Eight patients were in stage III and the remaining 8 patients in stage IV. Seven patients were diagnosed with lung cancer.

\section{Pharmacokinetics of Fentanyl after Fentanyl Tape Application}

The individual serum concentration-time curves of fentanyl and pharmacokinetic parameters after application of the 2.1- or 4.2-mg fentanyl tape are shown in figures 1 and 2, and table 2 . One patient treated with the 2.1-mg dose showed markedly increased serum fentanyl concentrations after fentanyl tape application. The null hypothesis of the Shapiro-Wilk test was performed on 
Fig. 1. Individual serum fentanyl concentration profiles after a single application of a fentanyl tape at 2.1 (a) or $4.2 \mathrm{mg}$ (b) in Japanese patients with cancer pain.

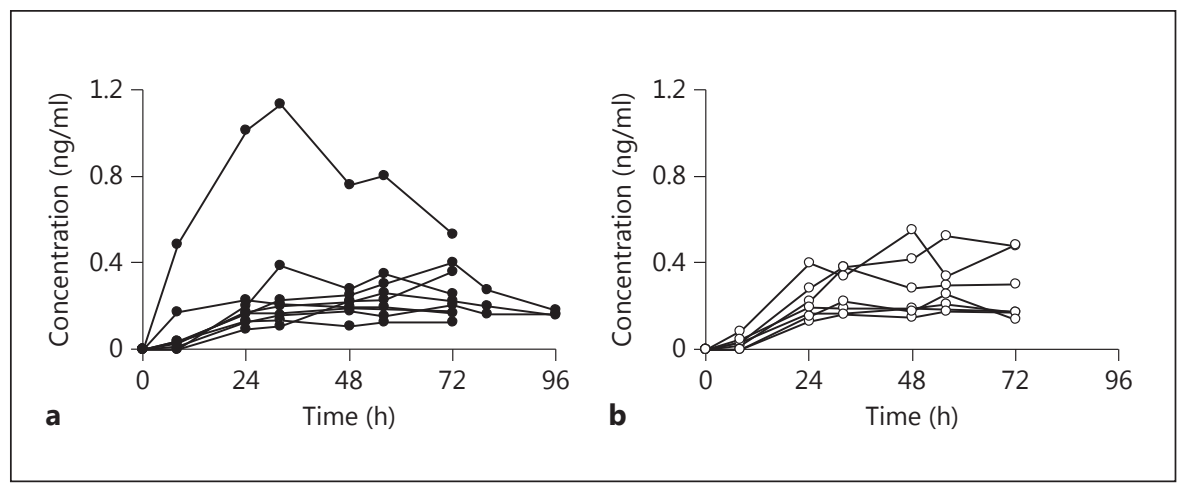

Table 1. Clinical and demographic characteristics of the study participants

\begin{tabular}{|c|c|c|}
\hline Dose & $2.1 \mathrm{mg}$ & $4.2 \mathrm{mg}$ \\
\hline \multicolumn{3}{|l|}{ Sex } \\
\hline Male & 10 & 6 \\
\hline Female & 0 & 0 \\
\hline \multicolumn{3}{|l|}{ Age, years } \\
\hline Mean & 70 & 68 \\
\hline Range & $56-81$ & $58-74$ \\
\hline \multicolumn{3}{|l|}{ Height, cm } \\
\hline Mean & 161.5 & 164.3 \\
\hline Range & $157.7-165.2$ & $158.4-174.0$ \\
\hline \multicolumn{3}{|l|}{ Weight, kg } \\
\hline Mean & 56.4 & 55.3 \\
\hline Range & $46.7-72.0$ & $47.5-66.4$ \\
\hline \multicolumn{3}{|l|}{ BMI } \\
\hline Mean & 21.7 & 20.4 \\
\hline Range & $17.8-27.5$ & $18.4-22.3$ \\
\hline \multicolumn{3}{|l|}{ Cancer } \\
\hline Tongue & 0 & 1 \\
\hline Oropharyngeal & 1 & 0 \\
\hline Hypopharyngeal & 1 & 1 \\
\hline Stomach & 0 & 1 \\
\hline Gallbladder & 0 & 1 \\
\hline Lung & 6 & 1 \\
\hline Bladder & 1 & 0 \\
\hline Kidney & 1 & 0 \\
\hline Thymoma & 0 & 1 \\
\hline \multicolumn{3}{|l|}{ Stage } \\
\hline III & 2 & 6 \\
\hline IV & 8 & 0 \\
\hline
\end{tabular}

$\mathrm{C}_{\max }$ and $\mathrm{AUC}_{0-72}$ of the patient. As a result, the $\mathrm{p}$ values of the parameters were $\mathrm{p}<0.0003$ and $\mathrm{p}<0.0001$, respectively, indicating an outlier. Therefore, mean pharmacokinetic parameters were calculated in the 15 patients, excluding the outlier.
Table 2. Pharmacokinetic parameters of serum fentanyl, ALT and AST concentrations after a single application of a fentanyl tape (2.1 or $4.2 \mathrm{mg}$ ) in Japanese patients with cancer pain

\begin{tabular}{|c|c|c|c|c|c|c|c|c|}
\hline No. & $\begin{array}{l}\mathrm{C}_{\max } \\
\mathrm{ng} / \mathrm{ml}\end{array}$ & $\begin{array}{l}\mathrm{t}_{\max } \\
\mathrm{h}\end{array}$ & $\begin{array}{l}\mathrm{t}_{1 / 2(\sim 96 \mathrm{~h})}, \\
\mathrm{h}\end{array}$ & $\begin{array}{l}\mathrm{AUC}_{0-72} \\
\mathrm{ng} \cdot \mathrm{h} / \mathrm{ml}\end{array}$ & $\begin{array}{l}\text { Age, } \\
\text { years }\end{array}$ & $\begin{array}{l}\text { ALT, } \\
\text { IU/l }\end{array}$ & $\begin{array}{l}\text { AST, } \\
\text { IU/l }\end{array}$ & $\begin{array}{l}\mathrm{sCr} \\
\mathrm{mg} / \mathrm{dl}\end{array}$ \\
\hline \multicolumn{9}{|c|}{ Fentanyl tape $2.1 \mathrm{mg}$} \\
\hline 1 & 1.135 & $32^{\circ}$ & $\mathrm{NC}$ & 54.62 & 62 & 23 & 37 & 1.6 \\
\hline 2 & 0.133 & 32 & $\mathrm{NC}$ & 7.42 & 56 & 19 & 18 & 0.8 \\
\hline 3 & 0.200 & 48 & $\mathrm{NC}$ & 8.92 & 68 & 23 & 27 & 0.7 \\
\hline 4 & 0.191 & 48 & $\mathrm{NC}$ & 10.37 & 73 & 31 & 30 & 1.3 \\
\hline 5 & 0.402 & 72 & 21.9 & 15.03 & 73 & 7 & 18 & 1.3 \\
\hline 6 & 0.207 & 72 & 87.0 & 9.26 & 76 & 12 & 7 & 0.8 \\
\hline 7 & 0.362 & 72 & $\mathrm{NC}$ & 10.69 & 72 & 28 & 25 & 1.3 \\
\hline 8 & 0.230 & 24 & $\mathrm{NC}$ & 13.46 & 81 & 31 & 16 & 1 \\
\hline 9 & 0.263 & 56 & 49.1 & 12.39 & 62 & 15 & 28 & 0.7 \\
\hline 10 & 0.387 & 32 & $\mathrm{NC}$ & 16.68 & 81 & 36 & 38 & 0.6 \\
\hline Mean $^{1}$ & 0.264 & 51 & 52.7 & 11.6 & 71 & 22 & 23 & 0.9 \\
\hline $\mathrm{SD}^{1}$ & 0.097 & 19 & 32.7 & 3.0 & 8 & 10 & 9 & 0.3 \\
\hline \multicolumn{9}{|c|}{ Fentanyl tape $4.2 \mathrm{mg}$} \\
\hline 1 & 0.525 & 56 & $\mathrm{NC}$ & 22.56 & 71 & 21 & 21 & 0.7 \\
\hline 2 & 0.381 & 32 & $\mathrm{NC}$ & 17.80 & 58 & 10 & 32 & 0.9 \\
\hline 3 & 0.553 & 48 & $\mathrm{NC}$ & 24.44 & 74 & 14 & 12 & 1.0 \\
\hline 4 & 0.210 & 56 & $\mathrm{NC}$ & 11.37 & 67 & 16 & 26 & 0.8 \\
\hline 5 & 0.176 & 56 & $\mathrm{NC}$ & 8.71 & 68 & 14 & 17 & 1.5 \\
\hline 6 & 0.254 & 56 & $\mathrm{NC}$ & 10.79 & 69 & 14 & 17 & 1.1 \\
\hline Mean & 0.350 & 50.7 & $\mathrm{NC}$ & 15.95 & 67.8 & 15 & 21 & 1.0 \\
\hline SD & 0.162 & 9.7 & $\mathrm{NC}$ & 6.62 & 5.4 & 3.6 & 7.2 & 0.3 \\
\hline
\end{tabular}

$\mathrm{NC}=$ Not calculated; $\mathrm{sCR}=$ serum creatinine .

${ }^{1}$ The mean and SD were calculated for No. 2-10.

After a single application of the fentanyl tape to the 15 patients, serum fentanyl concentrations gradually increased (fig. 1). Serum fentanyl concentrations remained constant during the 72-hour application and decreased after detachment of the tape. $\mathrm{C}_{\max }$ and $\mathrm{AUC}_{0-72}$ for the
12

Oncology 2014;86:10-15 DOI: $10.1159 / 000356625$
Saito/Fujii/Saito/Shimada/Fujiwara/ Kobayashi 


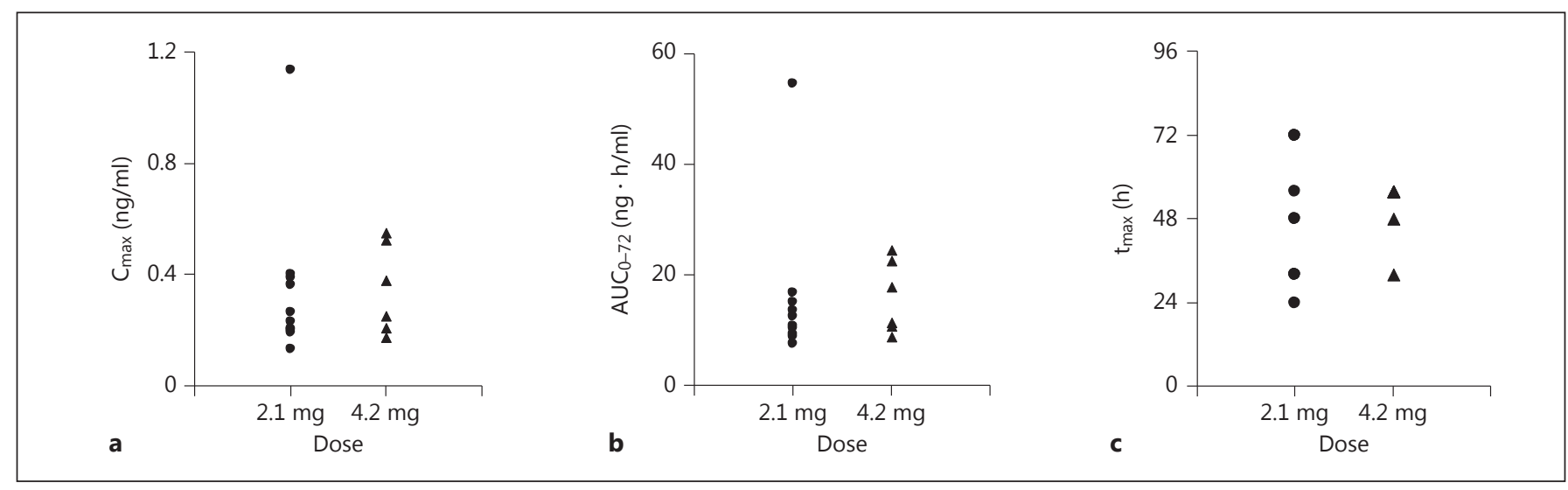

Fig. 2. Pharmacokinetics parameters, $C_{\max }(\mathbf{a}), A_{U C C_{0-72}}(\mathbf{b})$ and $t_{\max }(\mathbf{c})$ of serum fentanyl concentrations after a single application of a fentanyl tape (2.1 or $4.2 \mathrm{mg}$ ) in Japanese patients with cancer pain.

Fig. 3. Relationship between age $(\mathbf{a}, \mathbf{b})$ or $\mathrm{BMI}(\mathbf{c}, \mathbf{d})$ and $\mathrm{C}_{\max }(\mathbf{a}, \mathbf{c})$ or $\mathrm{AUC}_{0-72}(\mathbf{b}$, d) of serum fentanyl concentrations after a single application of a fentanyl tape at 2.1 ( ) and $4.2 \mathrm{mg}(\mathrm{O})$ in Japanese patients with cancer pain.

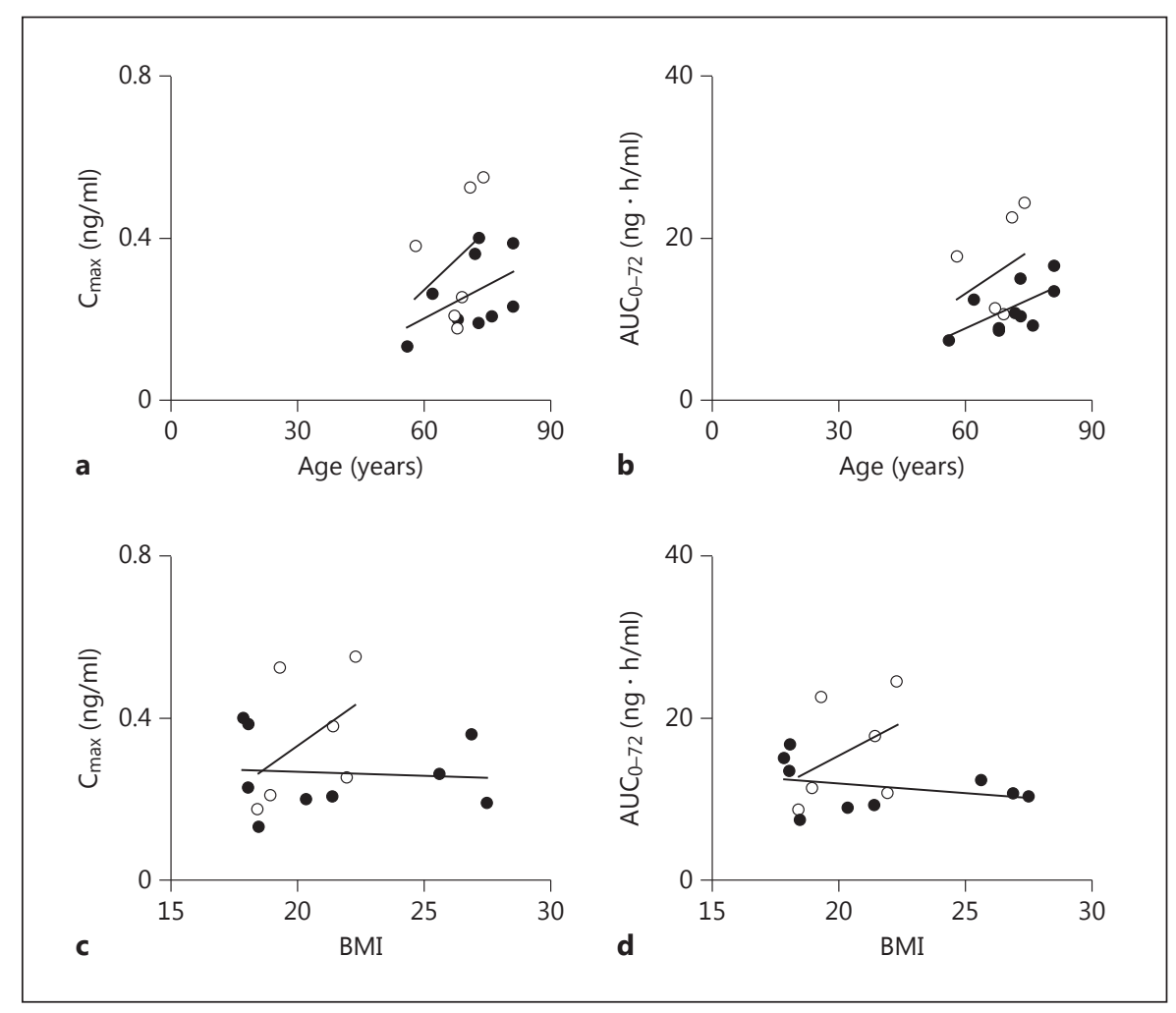

2.1 - and 4.2 - $\mathrm{mg}$ tapes were 0.26 and $0.35 \mathrm{ng} / \mathrm{ml}$, and 11.58 and $15.95 \mathrm{ng} \cdot \mathrm{h} / \mathrm{ml}$, respectively. The $\mathrm{C}_{\max }$ and $\mathrm{AUC}_{0-72}$ tended to increase with the dosage from 2.1 to $4.2 \mathrm{mg}$, and $\mathrm{t}_{\max }$ was not significantly different $(48.8$ and $50.7 \mathrm{~h}$, respectively; $\mathrm{t}$ test, $\mathrm{p}=1.00$ ). In 3 patients treated with 2.1 $\mathrm{mg}$, the elimination half-life after detachment was calculated, resulting in a mean of $52.7 \mathrm{~h}$.
Clinical Parameters and $C_{\text {max }}$ or $A U C_{0-72}$

Regarding relationships between clinical parameters (age, ALT, AST or serum creatinine) and $\mathrm{C}_{\max }$ or $\mathrm{AUC}_{0-72}$, coefficients of correlation were low $(<0.6)$ except for age (table 3 ). The patients ranged in age from 56 to 81 years. At the dose of $2.1 \mathrm{mg}$, a modest correlation between age and $\mathrm{AUC}_{0-72}$ was observed $(\mathrm{r}=0.62$; fig. 3 ). 
Table 3. Relationships between clinical parameters (age, ALT, AST, serum creatinine or BMI) and $\mathrm{C}_{\max }$ or $\mathrm{AUC}_{0-72}$ after a single application of a fentanyl tape at 2.1 or $4.2 \mathrm{mg}$ in Japanese patients with cancer pain

\begin{tabular}{|c|c|c|c|c|}
\hline & & $\mathrm{R}$ & $\mathrm{R}^{2}$ & $\mathrm{p}$ \\
\hline \multicolumn{5}{|c|}{ Fentanyl tape $2.1 \mathrm{mg}$} \\
\hline \multirow[t]{5}{*}{$\mathrm{C}_{\max }$} & Age & 0.48 & 0.23 & 0.19 \\
\hline & ALT & 0.02 & 0.0006 & 0.95 \\
\hline & AST & 0.38 & 0.11 & 0.38 \\
\hline & Serum creatinine & 0.25 & 0.07 & 0.51 \\
\hline & $\mathrm{BMI}$ & 0.08 & 0.006 & 0.84 \\
\hline \multirow[t]{5}{*}{$\mathrm{AUC}_{0-72}$} & Age & 0.62 & 0.39 & 0.07 \\
\hline & ALT & 0.20 & 0.04 & 0.61 \\
\hline & AST & 0.39 & 0.15 & 0.30 \\
\hline & Serum creatinine & 0.03 & 0.001 & 0.94 \\
\hline & BMI & 0.30 & 0.09 & 0.43 \\
\hline \multicolumn{5}{|c|}{ Fentanyl tape $4.2 \mathrm{mg}$} \\
\hline \multirow[t]{5}{*}{$\mathrm{C}_{\max }$} & Age & 0.34 & 0.11 & 0.52 \\
\hline & ALT & 0.28 & 0.08 & 0.59 \\
\hline & AST & 0.19 & 0.04 & 0.72 \\
\hline & Serum creatinine & 0.54 & 0.29 & 0.27 \\
\hline & BMI & 0.46 & 0.21 & 0.36 \\
\hline \multirow[t]{5}{*}{$\mathrm{AUC}_{0-72}$} & Age & 0.29 & 0.08 & 0.38 \\
\hline & ALT & 0.25 & 0.06 & 0.63 \\
\hline & AST & 0.12 & 0.02 & 0.82 \\
\hline & Serum creatinine & 0.58 & 0.33 & 0.23 \\
\hline & BMI & 0.43 & 0.18 & 0.40 \\
\hline
\end{tabular}

\section{Safety}

Adverse drug reactions and adverse events after a single application of a fentanyl tape in Japanese patients with cancer pain are shown in table 4 . There was no grade 3 toxicity, and only grade 1 ALT and AST elevations occurred in 1 patient treated with $2.1 \mathrm{mg}$. Skin toxicity, such as eruption, was not observed in any patient.

\section{Discussion}

Acrylic adhesives, which are made of 2-ethylhexyl acrylate-vinyl ingredients, are widely used as fentanyl tapes now. A novel delivery system of fentanyl using a rubber adhesive in a release liner was developed, and the rubber adhesive has little irritability and good adhesion to the skin. In this study, this novel delivery system was investigated regarding its pharmacokinetic and safety profiles in Japanese patients with cancer pain.

We investigated the pharmacokinetics of fentanyl tapes containing fentanyl at dosages of 2.1 or $4.2 \mathrm{mg}$. The
Table 4. Adverse drug reactions and adverse events after a single application of a fentanyl tape in Japanese patients with cancer pain

\begin{tabular}{llll}
\hline Events & $\begin{array}{l}2.1 \mathrm{mg} \\
(\mathrm{n}=10)\end{array}$ & & $\begin{array}{l}4.2 \mathrm{mg} \\
(\mathrm{n}=6)\end{array}$ \\
\cline { 2 - 3 } & $\mathrm{n} \%$ & & $\mathrm{n} \%$ \\
\hline
\end{tabular}

Adverse drug reactions

$\begin{array}{lllll}\text { ALT } \uparrow & 1 & 10 & 0 & 0 \\ \text { AST } \uparrow & 1 & 10 & 0 & 0\end{array}$

AST $\uparrow$

$\begin{array}{llll}1 & 10 & 0 & 0\end{array}$

Adverse events

Abdominal discomfort

ALT $\uparrow$

AST $\uparrow$

Blood albumin $\downarrow$

Blood calcium $\downarrow$

Blood creatinine $\uparrow$

Blood potassium $\downarrow$

Blood sodium $\downarrow$

Hematocrit $\downarrow$

Hemoglobin $\downarrow$

Lymphocyte count $\downarrow$

Neutrophil count $\downarrow$

Platelet count $\downarrow$

RBC count $\downarrow$

WBC count $\downarrow$

WBC count $\uparrow$

Protein urine present

Appetite $\downarrow$

Hiccups

\begin{tabular}{lrlc}
1 & 30 & 0 & 0 \\
3 & 30 & 0 & 0 \\
3 & 10 & 1 & 16.7 \\
1 & 20 & 2 & 33.3 \\
2 & 0 & 0 & 0 \\
0 & 0 & 1 & 16.7 \\
0 & 10 & 1 & 16.7 \\
1 & 10 & 2 & 33.3 \\
1 & 10 & 0 & 0 \\
4 & 40 & 2 & 33.3 \\
1 & 10 & 2 & 33.3 \\
1 & 10 & 1 & 16.7 \\
1 & 10 & 0 & 0 \\
1 & 10 & 0 & 0 \\
1 & 10 & 1 & 16.7 \\
1 & 10 & 1 & 16.7 \\
2 & 20 & 0 & 0 \\
1 & 10 & 0 & 0 \\
1 & 10 & 0 & 0 \\
\hline
\end{tabular}

$\mathrm{n}=$ Number of subjects; \% = incidence in percent; $\mathrm{RBC}=$ red blood cell; $\mathrm{WBC}=$ white blood cell. Medical Dictionary for Regulatory Activities/Japanese translation (version 12.1).

serum concentrations of fentanyl were sufficiently maintained for $72 \mathrm{~h}$ in the patients. In 15 of the 16 patients enrolled, $\mathrm{C}_{\max }$ and $\mathrm{AUC}_{0-72}$ increased with dosage from 2.1 to $4.2 \mathrm{mg}$, although $\mathrm{t}_{\max }$ was constant at either dose. In terms of clinical parameters and $\mathrm{C}_{\max }$ or $\mathrm{AUC}_{0-72}$, only a modest correlation $(r=0.62)$ was observed between age and $\mathrm{AUC}_{0-72}$ in serum fentanyl concentrations after a single application of the 2.1-mg fentanyl tape in Japanese patients with cancer pain. There may be reduced clearance of fentanyl and a prolonged half-life in elderly patients, resulting in increased $\mathrm{AUC}_{0-72}$. According to the information of the package inserts of the Durotep $\mathrm{MT}^{\circledR}$ patch used with acrylic adhesive [4], both $\mathrm{C}_{\max }$ and AUC were increased 1.1 times, and elimination half-life was prolonged 1.4 times in elderly healthy subjects, and the increases in the values were relatively small. 
As fentanyl is metabolized to inactive metabolites mainly by CYP3A4 [4] in the liver [5], hepatic diseases might influence its elimination process in the serum. Data from other studies on fentanyl suggest that pharmacokinetic parameters $\left(\mathrm{C}_{\max }\right.$ and $\left.\mathrm{AUC}\right)$ were increased in patients with hepatic impairment [6]. However, there was no significant correlation between ALT or AST and $\mathrm{C}_{\max }$ or $\mathrm{AUC}_{0-72}$ in this study. One explanation might be the entry criteria requiring ALT and AST $<100 \mathrm{IU} / \mathrm{l}$. In a previous report, renal insufficiency had no significant effect on pharmacokinetic properties after a bolus administration of fentanyl [7]. In patients with serum creatinine $<1.6$ $\mathrm{mg} / \mathrm{dl}$, there was no significant correlation between serum creatinine and $\mathrm{C}_{\max }$ or $\mathrm{AUC}_{0-72}$ in this study.

The Shapiro-Wilk test indicated one outlier in $\mathrm{C}_{\max }$ and $\mathrm{AUC}_{0-72}$. This patient showed markedly increased serum fentanyl concentrations compared to the other patients after application of the 2.1-mg fentanyl tape. We investigated the patient's characteristics and searched for causes. Temperature-dependent increases in the release of fentanyl from the matrix fentanyl tape are known [8]. However, this patient showed no elevated body temperature. On the day fentanyl was applied, he stayed in a room with temperature of $25^{\circ} \mathrm{C}$ and was not under daylight. His ALT and AST were 23 and 37 IU/l, respectively. Meanwhile, this patient was co-administered with $150 \mathrm{mg}$ erlotinib, which was metabolized by CYP3A4. The $\mathrm{K}_{\mathrm{i}}$ of er- lotinib for CYP3A4 is about $10 \mu \mathrm{mol} / \mathrm{l}(4.3 \mu \mathrm{g} / \mathrm{ml})$ [9], and $\mathrm{C}_{\max }$ of erlotinib is about $1-2.5 \mu \mathrm{g} / \mathrm{ml}$ at the $150-\mathrm{mg}$ dose. Therefore, erlotinib might have affected fentanyl metabolism.

We did not encounter any notable problems concerning the safety of fentanyl tapes at 2.1 and $4.2 \mathrm{mg}$ after a single application. In this study, there were no skin toxicities with this new rubber adhesive. There were no grade 3 toxicities, and only grade 1 ALT and AST elevations were noted in 1 patient receiving $2.1 \mathrm{mg}$. From these results, adverse reactions are considered to be acceptable.

In conclusion, the novel delivery system of fentanyl might be very promising for clinical pain management based on the results of our pharmacokinetic and safety investigations.

\section{Acknowledgment}

We thank all patients who participated in this study.

This research was supported by Meiji Seika Pharma Co., Ltd., and fentanyl patches were provided by Yutoku Pharmaceutical Industry Co., Ltd.

\section{Disclosure Statement}

The authors declare that there is no conflict of interest.

\section{References}

1 Gharagozlou P, Demrich H, David CJ, Lameh $\mathrm{J}$ : Activity of opioid ligands in cells expressing cloned mu opioid receptors. BMC Pharmacol 2003;3:1-8.

2 Donner B, Zenz M, Tryba M, Strumpf M: Direct conversion from oral morphine to transdermal fentanyl: a multicenter study in patients with cancer pain. Pain 1996;64:527534.

3 Cashman JN, Dolin SJ: Respiratory and haemodynamic effects of acute postoperative pain management: evidence from published data. Br J Anaesth 2004;93:212-223.
4 Packcage inserts Durotep ${ }^{\circledR}$ MT Patch 2011, ed 4 (in Japanese). http://database.japic.or.jp/ pdf/newPINS/00055312.pdf.

5 Feierman DE, Lasker JM: Metabolism of fentanyl, a synthetic opioid analgesic, by human liver microsomes. Role of CYP3A4. Drug Metab Dispos 1996;24:932-939.

6 Rose PG, Macfee MS, Boswell MV: Fentanyl transdermal system overdose secondary to cutaneous hyperthermia. Anesth Analg 1993; 77:390-391.
Scholz J, Steinfath M, Schulz M: Clinical pharmacokinetics of alfentanyl, fentanyl and sufentanyl: an update. Clin Pharmacokinet 1996;31:275-292.

8 Newshan D: Heat-related toxicity with the fentanyl transdermal patch. J Pain Symptom Manage 1998;29:277-278.

9 Dong PP, Fang ZZ, Zhang YY, Ge GB, Mao YX, Zhu LL, Qu YQ, Li W, Wang LM, Liu CX, Yang L: Substrate-dependent modulation of the catalytic activity of CYP3A by erlotinib. Acta Pharmacol Sin 2010;32:399-407. 